\title{
Congenital intrascleral cyst
}

This article was published in the following Dove Press journal:

Clinical Ophthalmology

12 May 20II

Number of times this article has been viewed

\section{Müslime Akbaba' \\ Gülhanım Hacıyakupoğlu² \\ Aysun Uğuz ${ }^{3}$ \\ Șafak Karslıoğlu' \\ Zeynel Karcıoğlu ${ }^{4}$}

'İstanbul Oculoplastic and Orbital Surgery and Ocular Oncology Center, Sișli/İstanbul, Turkey; ${ }^{2}$ Department of Ophthalmology of Faculty Medicine, Çukurova University, Balcali/Adana,

Turkey; ${ }^{3}$ Department of Pathology of Faculty Medicine, Çukurova University, Balcali/Adana, Turkey; ${ }^{4}$ Department of Ophthalmology, University of Virginia Health Sciences Center, Charlotte, NC, USA
Correspondence: Müslime Akbaba Professor of Ophthalmology, İstanbul Oculoplastic and Orbital Surgery and Ocular Oncology Center, Halaskargazi Cad. No. 165/3, 3438I, Șișli/İstanbul, Turkey

Tel +902122329221

Fax +902122466133

Email muslimeakbaba@yahoo.com
Abstract: Congenital intrascleral cysts are rare. They are mostly located at the limbus with corneal involvement. We report a case of a 30-month-old boy with a bulber conjunctival cyst noticed at birth. The lesion enlarged over the following months but did not involve the cornea. During surgery the cyst proved to be intrascleral and a complete excision was carried out. The remaining defect was repaired with banked fascia lata. The histopathology revealed a scleral cyst wall lined by nonkeratinizing squamous epithelium with no goblet cells. We conclude that congenital intrascleral epithelial cysts are rare but should be considered in differential diagnosis of external eye cystic lesions. In our case, early excision and repair with fascia lata led to an uncomplicated postoperative course of 6 years.

Keywords: intrascleral cyst, epithelial cyst, banked fascia lata

\section{Introduction}

Congenital intrascleral cysts are unusual clinical conditions with uncertain etiology. The lesions are usually located at the limbus with corneal and scleral components. In this report, we present a case with progressively enlarging congenital intrascleral cyst without corneal involvement in a 30-month-old boy, and describe its clinical and histopathologic features and surgical management.

\section{Case report}

A 30-month-old boy presented to the clinic with a bulbar subconjunctival cystic mass of the right eye (Figure 1A). The lesion was present at birth and had been gradually enlarging for 1 year. Delivery was uneventful and there was no history of ocular trauma or amniosynthesis.

A thin-walled, multilocular scleral cyst, measuring $5 \mathrm{~mm} \times 8 \mathrm{~mm}$ in its largest dimensions, was identified at the inferior nasal quadrant, extending from the medial canthus to the limbus of the right eye (Figure 1A, B, and C). There was no conjunctival congestion or vascularization, and the cornea was clear. Visual acuity was 1.0 with a "tumbling E" chart. The rest of the ocular examination in the right eye and the left eye was normal.

During surgery, saline hydrodissection was carried out with a 30-gauge needle to separate the underlying cyst wall from conjunctiva, confirming that the lesion was intrascleral. A conjunctival incision was made through the upper margin of the mass from the $3 \mathrm{o}$ 'clock position to the inner canthus to expose the anterior portion of the 


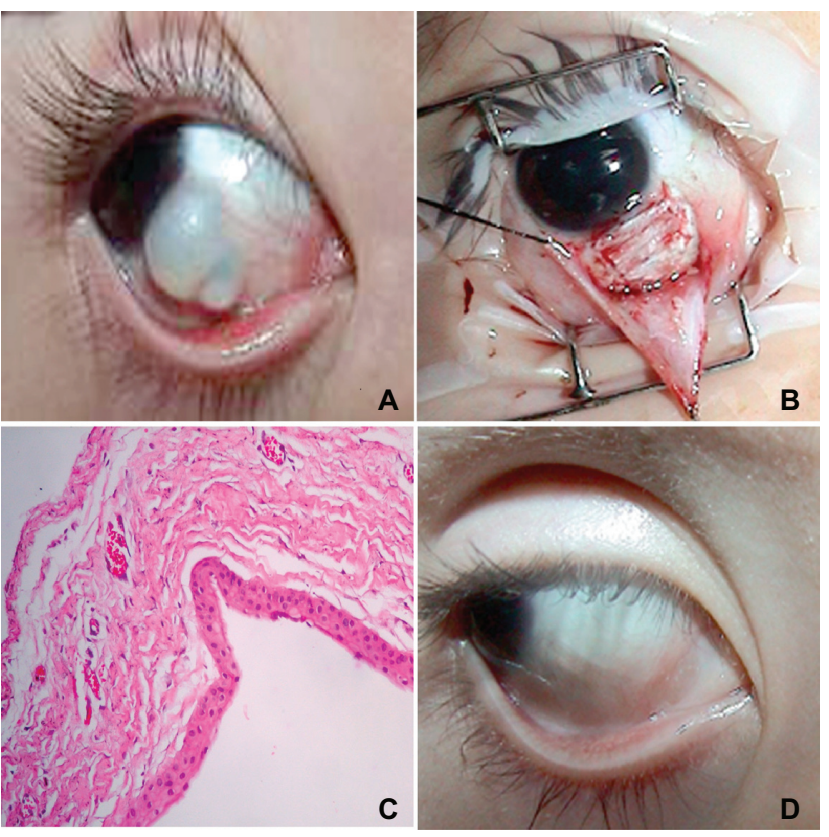

Figure I A) Multiloculated intrascleral cystic mass at presentation. B) Banked fascia lata covering the scleral defect after excision of the cyst. C) Photomicrograph of the cyst wall layered with nonkeratinized squamous epithelium (HE XI00). D) The appereance of the eye 6 months after surgery.

lesion by blunt dissection without perforating the cyst. The anterior portion of the cyst containing transparent fluid was exposed and removed carefully. The posterior aspect of the cyst was then gently cleaned with a Weck-cell sponge to be sure that no residual epithelium was left behind. After the total removal of the cyst, the sclera at the posterior aspect was noted to be very thin and the underlying choroid was clearly visible. This thin area was patched with preserved fascia lata using 8.0 vicryl sutures to prevent staphyloma formation (Figure 1B). Conjunctiva above the patch was also closed with 8.0 vicryl sutures. At the end of the surgery, $0.5 \mathrm{~mL}$ dexamethasone and $0.5 \mathrm{~mL}$ gentamicin were injected subconjunctivally. Topical tobramycine and prednisolone acetate were used postoperatively. Histopathologic examination revealed that the cyst wall was lined with multiple layers of nonkeratinized epithelial cells. No goblet cells were identified (Figure 1C). Minimal scar formation without scleral depression developed at the site of surgery. No other complications or recurrence took place during the 6 years postoperatively (Figure 1D).

\section{Discussion}

Intrascleral cysts develop due to sequestration of squamous epithelium within the anterior sclera. Congenital intrascleral cysts are seen less frequently than their acquired counterparts, which typically occur after ocular surgery or trauma. ${ }^{1}$ These congenital lesions are considered to be developmental defects that usually enlarge at the first year of life, as was the case in our patient. Generally, they are located at the limbus at birth as a nidus, but expansion of the cyst into the cornea may develop later in childhood. ${ }^{2,3}$ Vision is often affected due to the distortion and scarring caused by the lesion on and around the limbus. In our case, the vision was normal because of the absence of the corneal component. In one reported case, Mahmood and Awad ${ }^{3}$ stated that corneal involvement may not occur in patients up to 3 years of age, but the cyst may enlarge in later years to disturb visual acuity. Considering this possibility and due to the large size of the cyst in our patient, we operated early.

Histopathologic examination revealed that the cyst wall was lined with nonkeratinized epithelial cells without goblet cells. The presence of goblet cells is said to favor congenital origin. ${ }^{3}$ Rao et $\mathrm{al}^{2}$ reported the presence of glandular structures simulating lacrimal gland tissue and stated that this indicates the developmental nature of the lesion.

These cysts may recur postoperatively because of residual epithelium. Careful removal of the cyst wall, denaturation of remnants with saline and distilled water, and chemical coterization with trichloroacatic acid and tetracyclin injection are advised to prevent recurrence. ${ }^{4}$ In limbal cysts, peripheral lamellar keratoplasty is known to be effective to prevent the development of staphyloma and recurrence. ${ }^{5}$ In order to prevent staphyloma formation in our case, we utilized banked fascia lata, which worked well without complications. Based on our experience in this case, we would suggest that banked fascia lata may be considered as an alternative grafting material in defect restoration when banked human sclera is not readily available.

In conclusion, we report our experience with a congenital intrascleral cyst that was surgically repaired with the use of banked fascia lata and had an uncomplicated postoperative course of 6 years.

\section{Disclosure}

The authors report no conflict of interest with this work.

\section{References}

1. Kıratlı H, Türkçüoğlu P. Scleral cyst formation following extracapsular cataract extraction. Ophthalmic Surg Lasers Imaging. 2005;36(1): 67-69.

2. Rao SK, Fogla R, Bswas J, Padmanabhan P. Corneoscleral epithelial cysts: evidence of developmental etiology. Cornea. 1998;17(4):446-450. 
3. Mahmood MA, Awad A. Congenital sclerocorneal epithelial cyst. Am J Ophthalmol. 1998;126(5):741-742.

4. Graubart E, Hubbard GB 3rd. Giant intrascleral cyst treated with trichloroacetic acid. Arch Ophthalmol. 2008;126(3):438-439.
5. Sano Y, Okamoto S, Nishida K, et al. Peripheral lamellar keratoplasty for corneoscleral cyst: three case reports. Cornea. 1999;18(2):233-236.

\section{Publish your work in this journal}

Clinical Ophthalmology is an international, peer-reviewed journal covering all subspecialties within ophthalmology. Key topics include: Optometry; Visual science; Pharmacology and drug therapy in eye diseases; Basic Sciences; Primary and Secondary eye care; Patien Safety and Quality of Care Improvements. This journal is indexed on Submit your manuscript here: http://www.dovepress.com/clinical-ophthalmology-journal

\section{Dovepress}

PubMed Central and CAS, and is the official journal of The Society of Clinical Ophthalmology (SCO). The manuscript management system is completely online and includes a very quick and fair peer-review system, which is all easy to use. Visit http://www.dovepress.com/ testimonials.php to read real quotes from published authors. 